\title{
Insulin-like growth factor-I regulates glucose-induced mitochondrial depolarization and apoptosis in human neuroblastoma
}

\author{
GM Leinninger ${ }^{1}$, JW Russell ${ }^{\star, 1,2}$, CM van Golen ${ }^{1}$, A Berent ${ }^{1,2}$ and \\ EL Feldman ${ }^{1}$ \\ 1 Department of Neurology, University of Michigan, Ann Arbor, MI, USA \\ 2 Department of Neurology, Veterans Affairs Medical Center, Ann Arbor, MI, \\ USA \\ * Corresponding author. J Russell, Department of Neurology, University of \\ Michigan, 200 Zina Pitcher Place, 4410 Kresge III, Ann Arbor, Ml 48109-0585 \\ USA. Tel: 734763 3776; Fax: 734763 7686; E-mail: jruss@umich.edu
}

Received 20.12.02; revised 22.12.03; accepted 16.1.04; published online 23.4.04 Edited by ME Peter

\begin{abstract}
Neuroblastoma, a pediatric peripheral nervous system tumor, frequently contains alterations in apoptotic pathways, producing chemoresistant disease. Insulin-like growth factor (IGF) system components are highly expressed in neuroblastoma, further protecting these cells from apoptosis. This study investigates IGF-I regulation of apoptosis at the mitochondrial level. Elevated extracellular glucose causes rapid mitochondrial enlargement coupled with an increase in the mitochondrial membrane potential $\left(\Delta \Psi_{M}\right)$ followed by mitochondrial membrane depolarization (MMD), uncoupling protein 3 (UCP3) downregulation, caspase-3 activation and decreased $\mathrm{Bcl}-2$. MMD inhibition by Bongkrekic acid prevents high-glucoseinduced loss of UCP3 and apoptosis. Glucose exposure induces caspase- 9 cleavage within $30 \mathrm{~min}$, and caspase-9 inhibition prevents glucose-mediated apoptosis. IGF-I prevents caspase activation and mitochondrial events leading to apoptosis. These results suggest that elevated glucose produces early initiator caspase activation, followed by $\Delta \Psi_{M}$ changes, in neuroblastoma cells; in turn, IGF-I prevents apoptosis by preventing downstream caspase activation, maintaining $\Delta \Psi_{\mathrm{M}}$ and regulating $\mathrm{Bcl}$ proteins.

Cell Death and Differentiation (2004) 11, 885-896.

doi:10.1038/sj.cdd. 4401429

Published online 23 April 2004
\end{abstract}

Keywords: apoptosis; programmed cell death; neuroblastoma; mitochondria; IGF-I; UCP3

Abbreviations: IGF, insulin-like growth factor; IGF-I, insulin-like growth factor-I; IGF-II, insulin-like growth factor-II; IGF-IR, type I IGF receptor; PI3K, phosphatidylinositol 3-kinase; $\Delta \Psi_{\mathrm{M}}$, mitochondrial membrane potential; PTP, permeability transition pore; ANT, adenine nucleotide transporter; VDAC, voltage-dependent anion channel; MMD, mitochondrial membrane depolarization; UCPs, uncoupling proteins; UCP3, uncoupling protein 3; UCP2, uncoupling protein 2; PI, propidium iodide; Rh123, rhodamine
123; BKA, Bongkrekic acid; MEK1/2, extracellular signal-regulated kinase 1/2; MAPK, mitogen-activated protein kinase; C9DN, caspase-9 dominant negative; C8DN, caspase-8 dominant negative; FLS, forward light scatter

\section{Introduction}

Neuroblastoma is a childhood tumor of the nervous system arising through improper differentiation of the neural crest cells that normally form the adrenal medulla and the sympathetic nervous system. ${ }^{1}$ Neuroblastoma accounts for $8-10 \%$ of all childhood cancers, and approximately $40 \%$ of patients have metastatic disease refractory to treatment. ${ }^{2}$ While many other solid tumors respond to chemotherapeutic agents by undergoing a caspase-dependent death, ${ }^{3}$ neuroblastoma tumors frequently overexpress the antiapoptotic protein $\mathrm{Bcl}-2$ and/or have defects in the caspase- 8 mediated apoptotic pathway, resulting in chemoresistant disease. ${ }^{4}$ In our laboratory, we have focused on alternative methods for apoptotic induction in human neuroblastoma cells, including high-mannitol or -glucose exposure, in attempts to develop novel ways to augment the treatment of aggressive neuroblastoma. ${ }^{5,6}$

Increased expression of the insulin-like growth factor (IGF) ligands, IGF-I, IGF-II, and the type I IGF receptor (IGF-IR) is present in a wide range of human cancers, ${ }^{7}$ including lung, breast, thyroid, prostate, glioblastomas, rhabdomyosarcomas, leukemias and neuroblastoma (reviewed in Nechushtan et $a l^{8}{ }^{8}$. IGF-IR overexpression leads to cellular transformation, ${ }^{7,9}$ tumor proliferation ${ }^{10,11}$ and growth ${ }^{12}$ while disruption of IGF-IR expression reverses the transformed phenotype. ${ }^{7,9}$ In neuroblastoma, IGF expression is present in all stages of primary tumors. ${ }^{13}$ IGF-I or IGF-II coupled to IGF-IR promotes survival of human neuroblastoma cell lines, ${ }^{14,15}$ and inhibition of IGF-IR expression using antisense strategies inhibits tumor growth and induces regression of NBL tumors in mice. ${ }^{16}$ IGF-I and IGF-IR expression also protects neuroblastoma cells from apoptosis, primarily through downstream PI3K pathway signaling. . $6,10,17-19$ Therefore, targeting the IGF-IR may provide a new therapeutic approach to cancer treatment. ${ }^{12,20,21}$ Antisense IGF-IR strategies also enhance the susceptibility of Ewing's sarcoma to doxorubicin-induced apoptosis, ${ }^{22}$ implying a use for IGF-IR disruption in combinatorial drug therapy. ${ }^{23}$ Based on the above evidence, our laboratory seeks to understand how the IGF-IR protects neuroblastoma cells from apoptosis induced through different mechanisms.

One potential mechanism by which IGF-I blocks apoptosis is by preventing depolarization of the inner mitochondrial membrane potential $\left(\Delta \Psi_{\mathrm{M}}\right)$. Depolarization of mitochondria (loss of $\Delta \Psi_{\mathrm{M}}$ ) is now known to initiate the apoptotic cascade in many cells, including cells of neuronal origin. ${ }^{24-26} \Delta \Psi_{M}$ is regulated by the permeability transition pore (PTP), a complex 
of proteins that includes the adenine nucleotide transporter (ANT) in the inner mitochondrial membrane and the voltagedependent anion channel (VDAC)/porin in the outer mitochondrial membrane. ${ }^{24,27,28}$ These changes in mitochondrial function are associated with release of cytochrome $c$ and other proteins from the inner membrane space to the cytoplasm. $^{24,29}$

The release of mitochondrial proteins in response to toxic stimuli activates the caspase cell death proteases, essential end effectors of cell death. ${ }^{30-32}$ Upon release from the mitochondria, cytochrome $c$ binds to Apaf- 1 and caspase-9, forming a complex known as the apoptosome. ${ }^{33-36}$ Apoptosome formation results in activation of caspase-9, initiating a caspase cascade. ${ }^{33-36}$ Typically, the caspase cascade ends with caspase- 3 activation, the caspase most critical for apoptosis induction. ${ }^{24,25}$ In contrast to this pathway, apoptosis may also occur via a caspase-8-dependent pathway. ${ }^{33}$ Caspase- 8 is activated by death receptors; this leads to downstream mitochondrial alterations, once again producing caspase- 9 cleavage. ${ }^{33}$ However, as previously stated, the caspase-8 pathway is often compromised in neuroblastoma, leading to resistant disease. ${ }^{4}$

In neuroblastoma, the relationship between high-glucose, mitochondrial membrane depolarization (MMD), caspase activation, apoptosis and IGF-I rescue is unknown. In the current studies, we utilized $\mathrm{SH}-\mathrm{SY} 5 \mathrm{Y}$ human neuroblastoma cells to examine the role of mitochondrial changes and caspase cleavage in glucose-induced apoptosis and to determine the relevance of these changes to the survival activity of IGF-I. We show that glucose induces MMD, mitochondrial swelling and caspase-3 activation in $\mathrm{SH}-\mathrm{SY} 5 \mathrm{Y}$ cells. These events are dependent on PTP. We present new evidence that IGF-I-mediated signaling prevents apoptosis due to stabilization of $\Delta \Psi_{M}$ leading to inhibition of MMD and mitochondrial swelling. We further show that the effects of glucose on mitochondria are associated with a decrease in Bcl-2 protein levels and with downregulation of uncoupling proteins (UCPs), events that will promote induction of apoptosis. Finally, glucose induces a rapid induction of caspase-9, and caspase-9 inhibition prevents glucosemediated apoptosis. Caspase- 3 activation occurs independent of caspase- 9 induction, an event preventable by IGF-I. These studies advance our understanding of IGF-I-mediated rescue in neuroblastoma cells, which may ultimately lead to intervention in resistant disease.

\section{Results}

\section{High glucose induces MMD and mitochondrial enlargement}

Although there is excellent evidence for a role of changes in $\Delta \Psi_{\mathrm{M}}$ and swelling in non-neuronal apoptosis, the role of these mitochondrial changes in neuroblastoma is unknown. We were therefore interested in the contribution of these mitochondrial events to glucose-induced neuroblastoma apoptosis. To facilitate these investigations, we utilized $\mathrm{SH}$ SY5Y human neuroblastoma cells, an N-type neuroblastoma cell line, which is tumorigenic in vivo and in vitro, expresses $\mathrm{N}$ Myc and expresses Bcl antiapoptotic proteins. ${ }^{5,37,38}$ In the first set of experiments, we examined the effect of glucose on $\Delta \Psi_{M}$ in SH-SY5Y cells using rhodamine 123 (Rh123). Rh123 is a vital fluorescent dye preferentially taken up by mitochondria in a voltage-dependent manner such that Rh123 fluorescence is proportional to $\Delta \Psi_{\mathrm{M} \cdot}{ }^{39}$ In these experiments, cells were costained with propidium iodide (PI), a DNA intercalating dye commonly used to measure the extent of cell death. ${ }^{40}$ This costaining with $\mathrm{PI}$ coupled with fluorescent activated cell sorting (FACS) allowed us to gate only on live cells, thereby ignoring any Rh123 fluorescence due to dead cells.

Mitochondrial dysfunction has been associated with other models of cell death, but not with glucose-induced injury. ${ }^{24,30,31}$ When $\Delta \Psi_{\mathrm{M}}$ was measured over $24 \mathrm{~h}$, there was an initial increase in the mean Rh123 level to $150 \%$ of control (maximum at $3 \mathrm{~h}$ ) followed by a decline to sub-basal levels by $8 \mathrm{~h}$. This initial increase in Rh123 levels indicates either mitochondrial swelling or hyperpolarization ${ }^{27}$ (Figure 1a). Rh123 measurements were standardized during the time course experiments, and between experiments, by measuring values as a percent of control at the corresponding time period, and represent combined data from seven separate experiments. In the presence of increased glucose $(45 \mathrm{mM})$, there was a rapid two-fold rise in the percent of dead cells at $6 \mathrm{~h}$, followed by a progressive increase to three-fold above the
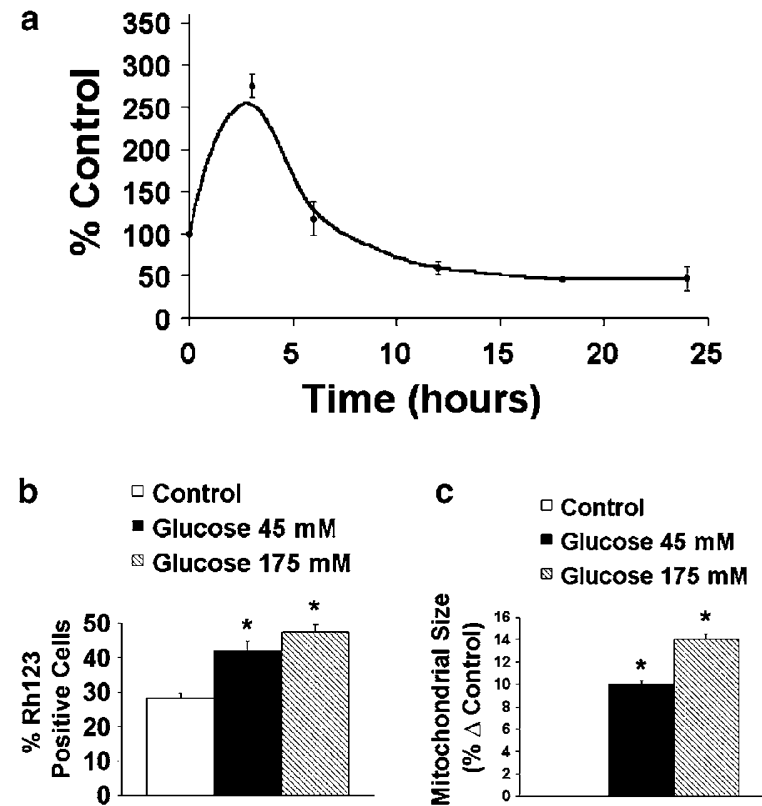

Figure 1 High glucose results in initial hyperpolarization followed by depolarization of $\Delta \Psi_{\mathrm{M}}$. (a) Using FACS analysis, there is an initial increase in Rh123 levels measured as peak Rh123 levels in relative fluorescent units and expressed as percent control. Rh123 levels peak at $3 \mathrm{~h}$, corresponding to enlargement of isolated mitochondria measured by FLS. This is followed by a decrease in $\Delta \Psi_{\mathrm{M}}$ corresponding to MMD over the next $24 \mathrm{~h}$. (b) Increasing glucose levels are associated with an increase in $\Delta \Psi$ measured as the \% Rh123positive cells at $3 \mathrm{~h}$ after addition of high glucose. The \% Rh123-positive cells is significantly increased with the addition of 45 or $175 \mathrm{mM}$ glucose compared to control media $\left({ }^{\star} P<0.01\right)$. (c) Increased concentrations of added glucose increase the size of isolated mitochondria from SH-SY5Y cells at $3 \mathrm{~h}$, measured by FACS analysis of FLS. Results indicate the $\%$ change (increase) compared to control (\% $\Delta$ Control). The mitochondrial size is significantly increased with the addition of 45 or $175 \mathrm{mM}$ glucose compared to control media ( ${ }^{*} P<0.05$ ) 
corresponding controls at $24 \mathrm{~h}(P<0.01)$. There was no significant change in control apoptosis during the experiment, although cell death was mildly increased at $24 \mathrm{~h}$.

To determine if higher glucose levels affected $\Delta \Psi_{M}$ and mitochondrial size, increasing concentrations of glucose (45$175 \mathrm{mM}$ ) were added to cultured SH-SY5Y cells; the inner mitochondrial membrane polarity was measured using Rh123 in whole cells, and mitochondrial size was measured in isolated mitochondria. Mitochondrial hyperpolarization increased at $3 \mathrm{~h}$ with higher concentrations of glucose as measured by the \% Rh123-positive cells (Figure 1b), and was significantly greater with $45 \mathrm{mM}$ glucose compared to control $(P<0.01)$. In contrast, by $6 \mathrm{~h}$ there was a dose-dependent decrease in $\Delta \Psi_{\mathrm{M}}$ to $30 \%$ less than control with $45 \mathrm{mM}$ glucose and $60 \%$ less than control with $175 \mathrm{mM}$ glucose at $6 \mathrm{~h}$ $(P<0.001)$. High glucose also induced mitochondrial enlargement in isolated mitochondria, to $10 \%$ greater than control with $45 \mathrm{mM}$ glucose $(P<0.05)$ and $14 \%$ greater than control with $175 \mathrm{mM}$ glucose (Figure 1c) at $3 \mathrm{~h}$. The maximal mitochondrial size using forward light scatter (FLS) was most easily measured at $3 \mathrm{~h}$.

\section{High glucose induces caspase-3 cleavage}

Activation of the caspase family of cell death proteases is essential for most types of apoptosis. ${ }^{24,25}$ The caspases normally exist as inactive proenzymes until they are either cleaved by other proteases or are activated by factors released from mitochondria. We and others have shown that activation of caspase-3 by a variety of toxic insults including high-dose mannitol in hyperosmolar concentrations plays an important role in apoptosis in SH-SY5Y cells. ${ }^{5,37,41}$ However, it has not been previously established whether high glucose, in non-hyperosmolar concentrations, induces caspase-3 activation in SH-SY5Y cells. As shown in Figure 2a, addition of glucose causes a dose-dependent increase in cleavage to the $17 \mathrm{kDa}$ cleavage band that is initially detected at $3 \mathrm{~h}$, corresponding to hyperpolarization of $\Delta \Psi_{\mathrm{M}}$ and increases to maximal levels at approximately $12 \mathrm{~h}$ (Figure $2 \mathrm{~b}$ ). Cleavage of the $32 \mathrm{kDa}$ procaspase protein can be observed with as little as $45 \mathrm{mM}$ glucose, but is greater with $175 \mathrm{mM}$ glucose, except at $24 \mathrm{~h}$ where caspase levels begin to fall as increasing numbers of cells die.

To further illustrate that caspase- 3 is activated during glucose-induced apoptosis in neuroblastoma cells, we plotted the ratio of cleaved caspase-3:GAPDH for each dose of glucose as a function of time. The percent cells showing cleaved caspase- 3 was $175 \pm 25 \%$ of control with $45 \mathrm{mM}$ glucose $(P<0.01)$, and $267 \pm 53 \%$ of control with $175 \mathrm{mM}$ glucose $(P<0.001)$ at the $12 \mathrm{~h}$ time point. These results show that glucose causes a dose-dependent activation of caspase3 in SH-SY5Y cells.

\section{Bongkrekic acid inhibits MMD, downregulation of UCPs and caspase-3 cleavage}

The next series of experiments determined the effect of adenine nucleotide translocase/voltage-dependent anion channel (ANT/VDAC) complex inhibition on the $\Delta \Psi_{\mathrm{M}}$. Bongk-
$3 \mathrm{H}$

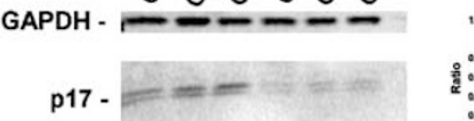

$6 \mathrm{H}$

GAPDH -

p17.
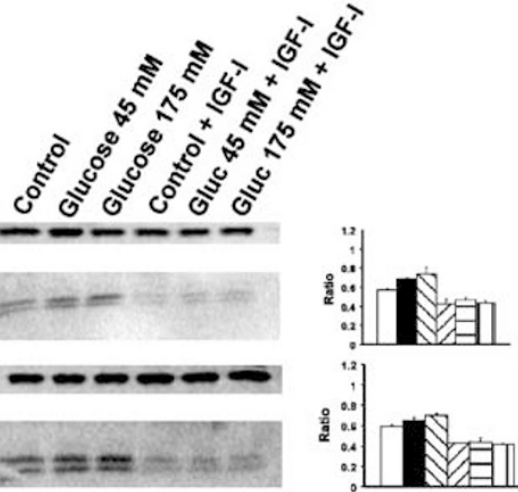

$12 \mathrm{H}$
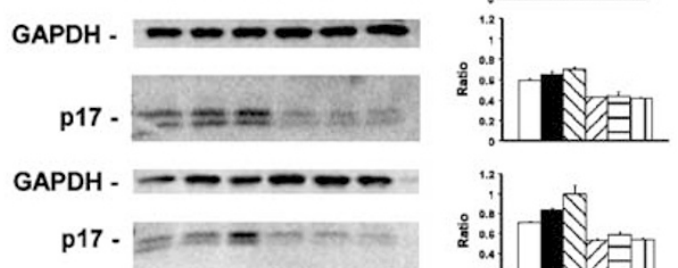

p17.

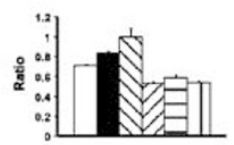

$24 \mathrm{H}$
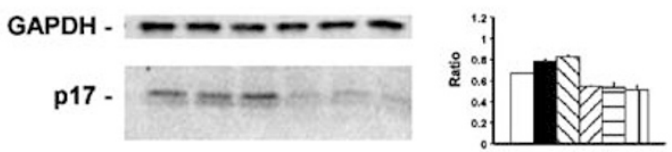

b

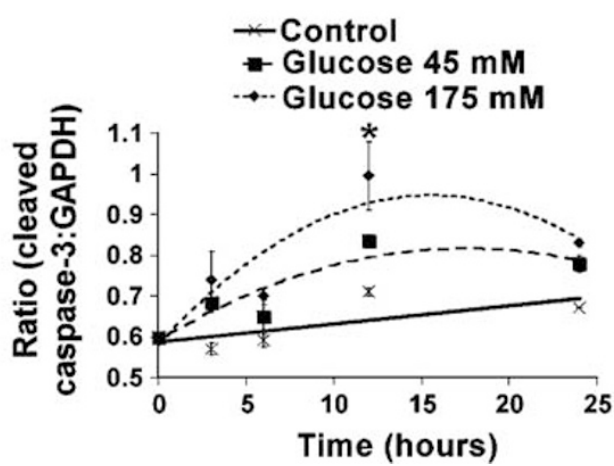

Figure 2 High glucose induces a dose-dependent cleavage of caspase-3 in SH-SY5Y cells that is blocked by IGF-I. (a) High glucose (45-175 mM) increases cleavage of caspase-3 in a dose-dependent manner. Immunoblotting of whole SH-SY5Y lysates with anti-caspase-3 antibody showed cleavage of procaspase3 to the active p17 subunit. At each time point $3-24 \mathrm{~h}$, there is an increase in caspase-3 cleavage compared to control. Results were plotted as a ratio to GAPDH used as a loading control. Increased cleavage is observed even with $45 \mathrm{mM}$ total glucose but is maximal at earlier time points with $175 \mathrm{mM}$ total glucose. In each case, caspase-3 cleavage was blocked by $10 \mathrm{nM}$ IGF-I. (b) Results for the ratio of cleaved caspase-3: GAPDH are plotted over $24 \mathrm{~h}$. At $0 \mathrm{~h}$, results were identical between groups. With both 45 and $175 \mathrm{mM}$ glucose, increased caspase- 3 cleavage is seen at $3 \mathrm{~h}$ and there is a gradual increase in caspase- 3 levels peaking at approximately $12 \mathrm{~h}$. The asterisk $\left(^{*}\right)$ represents statistically significant increases in cleaved caspase-3 with increased glucose concentration at the $12 \mathrm{~h}$ time point $(P<0.01)$

rekic acid (BKA) is an inhibitory ligand for the mitochondrial ANT. ${ }^{42,43}$ To determine if stabilization of $\Delta \Psi_{M}$ prevented cleavage of caspase-3 and apoptosis, SH-SY5Y cells were treated with $100 \mu \mathrm{M}$ BKA. In the presence of $45 \mathrm{mM}$ glucose, there was a decrease in $\Delta \Psi_{\mathrm{M}}(P<0.001)$ (Figure 3a), and an increase in the percent depolarized cells. Although the graph indicates data at $24 \mathrm{~h}$, similar results were obtained at 6 and $12 \mathrm{~h}$. Glucose induced a two-fold increase in the mean caspase level $(P<0.001)$ and a nine-fold increase in the percent caspase-positive cells at $6 \mathrm{~h}$ (Figure $3 \mathrm{~b}$ ). With $100 \mu \mathrm{M}$ BKA, glucose-induced MMD (Figure 3a) and caspase-3 
a
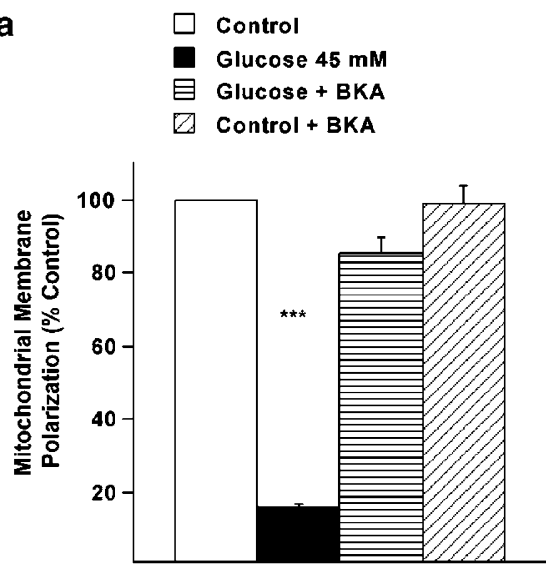

b

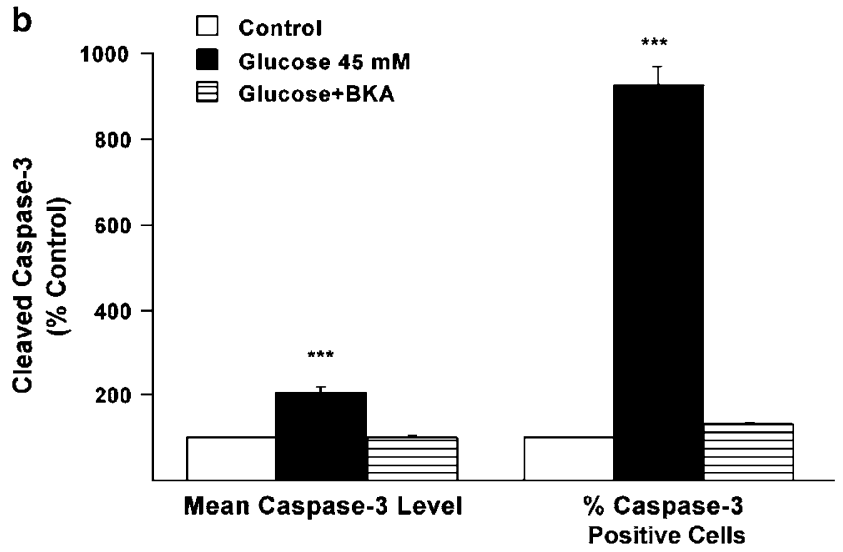

Figure 3 Inhibition of the ANT/VDAC complex by BKA inhibits MMD and caspase activation. (a) SH-SY5Y cells were treated with DMEM \pm high glucose for a period of $24 \mathrm{~h}$. The graph indicates the mean Rh123 level compared to control (control $=100 \%$ ). With $45 \mathrm{mM}$ total glucose, there was an $84 \%$ decrease in $\Delta \Psi_{\mathrm{M}}$ using Rh123, compared to control $(P<0.001)$. Depolarization of the inner mitochondrial membrane was blocked by $100 \mu \mathrm{M}$ BKA. There was no statistically significant difference between control and control + BKA at $24 \mathrm{~h}$. (b) BKA blocks glucose-induced cleavage of caspase-3 in SH-SY5Y cells measured using a DEVD-AMC fluorogenic substrate. The graph indicates cleavage of caspase-3 compared to control (control $=100 \%$ ). Neuroblastoma cells were treated with high glucose ( $45 \mathrm{mM}$ total glucose) $\pm 100 \mu \mathrm{M}$ BKA for a period of $6 \mathrm{~h}$. BKA acts by blocking the ANT/VDAC complex of the mitochondria and prevents loss of $\Delta \Psi_{\mathrm{M}}$. In the presence of BKA, there is reduced caspase-3 cleavage even in the presence of $45 \mathrm{mM}$ total glucose, indicating that inhibition of mitochondrial depolarization is critical in preventing apoptosis. ${ }^{\star \star \star} P<0.001$ compared to control

cleavage (Figure $3 \mathrm{~b}$ ) is blocked. With $100 \mu \mathrm{M} \mathrm{BKA}$, there was no statistical difference between control and glucose + BKA for MMD or for caspase-3 activation. BKA alone had no significant effect on MMD or caspase cleavage in control cells. Therefore, our results demonstrate that in SH-SY5Y cells, PTP opening results in caspase- 3 activation.

We then determined if stabilization of $\Delta \Psi_{\mathrm{M}}$ by BKA would affect UCPs known to act as proton pump regulators. In the presence of $45 \mathrm{mM}$ glucose, there was a decrease in uncoupling protein 3 (UCP3) protein levels that was inhibited by optimal levels of BKA consistent with BKA preventing ultimate MMD (Figure 4). BKA under control conditions slightly decreased the ratio of UCP3:GAPDH, possibly because BKA in the absence of high glucose would cause sustained mitochondrial membrane hyperpolarization that in

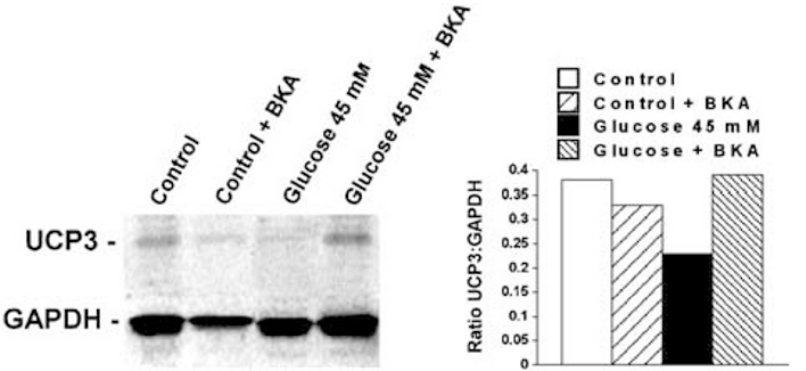

Figure 4 High-glucose-induced reduction in UCP3 levels is blocked by BKA. The blot indicates UCP3 protein levels in SH-SY5Y cells at $6 \mathrm{~h}$. SH-SY5Y cells were cultured in control medium or high $(45 \mathrm{mM})$ glucose $+100 \mu \mathrm{M}$ BKA for a period of $6 \mathrm{~h}$. Blots were developed with UCP3 antibody (32-35 kDa) on a $12 \%$ gel, and for GAPDH as a leading control. The graph indicates the ratio of UCP3: GAPDH in each lane.UCP3 levels decrease in the presence of high glucose. This is blocked by $100 \mu \mathrm{M}$ BKA

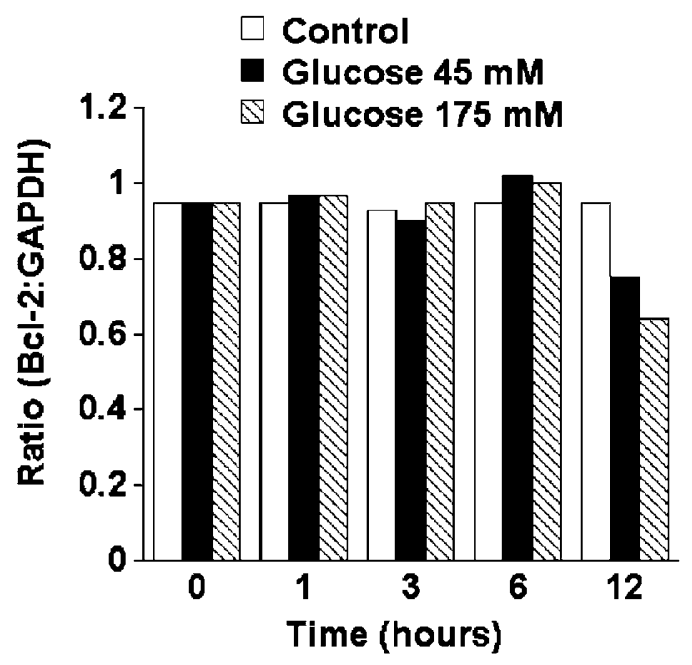

Figure 5 IGF-I prevents a decrease in Bcl-2 protein levels induced by high glucose. Immunoblots were performed on whole SH-SY5Y lysates using a monoclonal antibody against $\mathrm{Bcl}-2$. The graph indicates changes in the ratio of total Bcl-2: GAPDH on immunoblots performed over $12 \mathrm{~h}$. Bcl-2 protein levels were unchanged in high glucose compared to control conditions at $1-6 \mathrm{~h}$, but were measurably smaller in high glucose at $12 \mathrm{~h}$

itself would induce mitochondrial damage. ${ }^{44}$ Uncoupling protein 2 (UCP2) levels in the presence of high glucose were reduced similar to UCP3, although levels of protein expression of UCP2 are less in SH-SY5Y cells (data not shown).

\section{Effects of glucose on Bcl family members}

The $\mathrm{Bcl}-2$ family is a group of related proteins that either promote or counteract apoptosis and are thought to regulate mitochondrial function. ${ }^{24,25} \mathrm{Bcl}-2$ prevents apoptosis in response to a wide variety of stimuli, apparently by inhibiting MMD. ${ }^{27,45}$ In contrast, Bax promotes apoptosis by enhancing MMD. ${ }^{46} \mathrm{~A}$ reduction in Bcl-2 levels was not visible at $6 \mathrm{~h}$ but could be observed by $12 \mathrm{~h}$ (Figure 5). However, glucose did not affect Bax levels in SH-SY5Y cells (data not shown). 


\section{Effects of IGF-I on $\Delta \Psi_{M}$ and mitochondrial enlargement}

IGF-I and IGF-IR expression protects neuroblastoma cells from apoptosis and inhibition of IGF-IR expression induces neuroblastoma tumor regression in mice, likely through an apoptotic death of tumor cells. ${ }^{16}$ Moreover, we have shown that IGF-I prevents glucose-induced apoptosis in untransformed cells of neuronal origin, ${ }^{4,48}$ although the intermediate pathways leading to apoptosis are unknown. We therefore wanted to determine whether IGF-I affects mitochondrial function in neuroblastoma cells. Figure 6 a shows the effects of $45 \mathrm{mM}$ glucose and $10 \mathrm{nM}$ IGF-I alone and in combination on mitochondrial size. Similar to the results in Figure 1, a $3 \mathrm{~h}$ treatment with $45 \mathrm{mM}$ glucose caused a $10 \%$ increase in mitochondrial size compared to control. IGF-I alone at $10 \mathrm{nM}$ caused a very slight change in mitochondrial size (Figure 6a). Most importantly, IGF-I prevented glucose-induced mitochondrial swelling ( $1 \%$ decrease versus control). The PI3K inhibitor LY294002 blocked IGF-I regulation of mitochondrial size, allowing mitochondrial enlargement in the presence of high glucose (Figure 6a). In contrast, the mitogen-activated protein kinase extracellular signal-regulated kinase (MEK1/2) inhibitor PD98059 did not block IGF-I regulation of mitochondrial size. LY294002 and PD98059 alone had no significant effect on mitochondrial size compared to control (data not shown).

Figure $6 \mathrm{~b}$ shows a similar protective effect of IGF-I on glucose-induced MMD. Treatment of cells for $6 \mathrm{~h}$ with $45 \mathrm{mM}$ glucose alone caused an approximately $40 \%$ decrease in $\Delta \Psi_{\mathrm{M}}$. When $10 \mathrm{nM}$ IGF-I was added along with $45 \mathrm{mM}$ glucose, there was a $5 \%$ increase in $\Delta \Psi_{M}$ compared to control. Interestingly, $10 \mathrm{nM}$ IGF-I alone caused an increase in Rh123 fluorescence, but Figure 5a shows that this is not due to mitochondrial swelling. Rather, this effect of IGF-I likely reflects hyperpolarization of $\Delta \Psi_{\mathrm{M}}$. Inhibition of PI3K by LY294002 blocked IGF-I stabilization of $\Delta \Psi_{\mathrm{M}}$, whereas the MEK inhibitors PD98059 and U0126 only partially reversed the effect of IGF-I on $\Delta \Psi_{\mathrm{M}}$.

\section{IGF-I prevents caspase activation}

Next, a protective effect of IGF-I was also observed at the level of caspase-3 activation. We examined caspase-3 activity at $6 \mathrm{~h}$ after adding glucose using DEVD-AMC, a fluorogenic and cell-permeable substrate for caspase-2, -3 and $-7 .{ }^{49}$ As in Figure 2, similar results were found using the cell-permeable caspase-3 substrate DEVD-AMC (Figure 7). The addition of $45 \mathrm{mM}$ glucose increased the mean caspase-3 level (Figure 7$)$ on FACS $(P<0.001)$ as previously observed using Western immunoblotting (Figure 2). IGF-I decreased the mean caspase-3 level $20 \%$ below control in the presence of glucose, and was statistically different from both highglucose conditions $(P<0.001)$ and from control $(P<0.001)$. Similarly, IGF-I alone decreased the mean caspase-3 level $23 \%$ below control $(P<0.001)$. Cleavage of DEVD-AMC was blocked by Ac-DEVD-CHO (data not shown), indicating that this activity is primarily due to activated caspase- 3 . $^{49}$

Similar to the results with MMD, inhibition of both PI3K and MAPK/MEK signaling reduced the antiapoptotic effect of IGF-I in cells treated with high glucose for $6 \mathrm{~h}$ (Figure 7). LY294002
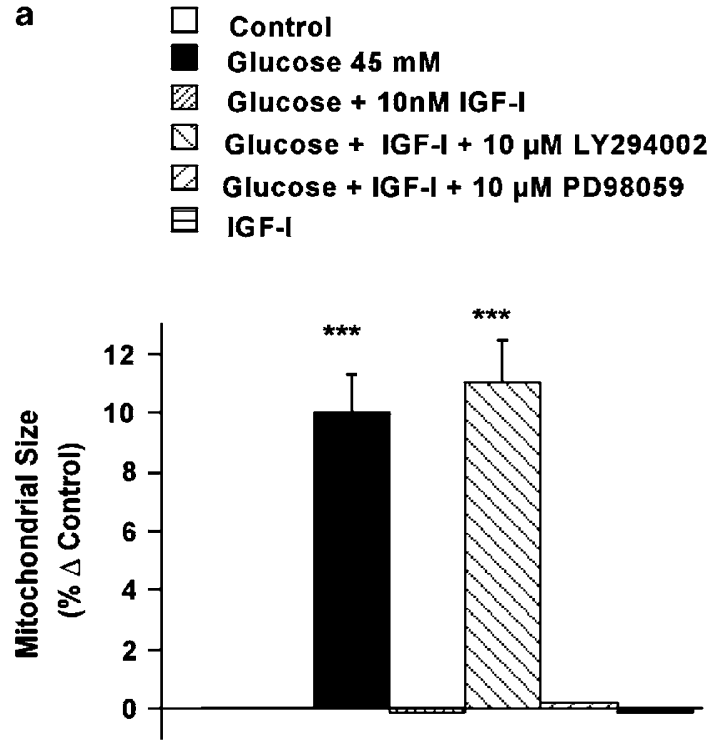

b
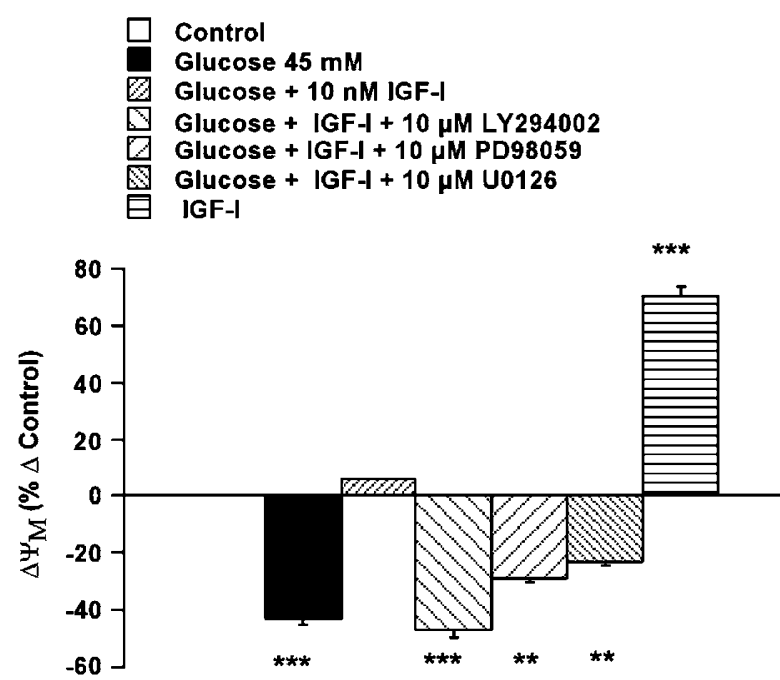

Figure 6 IGF-I inhibits changes in mitochondrial function induced by high glucose. (a) The graph indicates the percent change from control in mitochondrial size (\% $\Delta$ Control) measured using FLS of Rh123 from FACS analysis. With $45 \mathrm{mM}$ total glucose, there was a $10 \%$ increase in the mean size of isolated mitochondria from SH-SY5Y cells, compared to control. IGF-I (10 nM) prevented enlargement in mitochondria even in the presence of $150 \mathrm{mM}$ glucose. The PI3K inhibitor LY294002 $(10 \mu \mathrm{M})$ blocked IGF-I inhibition of mitochondrial swelling. In contrast, the MEK inhibitor PD98059 $(10 \mu \mathrm{M})$ and IGF-I alone had no effect on mitochondrial size compared to control mitochondria. (b) The graph indicates the $\%$ change in $\Delta \Psi_{\mathrm{M}}$ compared to control $\left(\Delta \Psi_{\mathrm{M}}\right)$ using the mean Rh123 level from FACS analysis. Values are expressed as percent change from control $(\% \Delta$ Control). IGF-I inhibits the high-glucose-induced decrease in $\Delta \Psi_{\mathrm{M}}$. IGF-I alone increases the mean Rh123 levels above control, consistent with an elevated $\Delta \Psi_{\mathrm{M}}$. In contrast, LY294002 $(10 \mu \mathrm{M})$ blocks IGF-I inhibition of MMD. The MEK inhibitors PD98059 and U0126 (both $10 \mu \mathrm{M}$ ) partially inhibit IGF-I regulation of $\Delta \Psi_{\mathrm{M} .}{ }^{* *} P<0.01 ;{ }^{* \star *} P<0.001$ compared to control

almost completely blocked IGF-I protection, whereas PD98059 and U0126 reduced the neuroprotective effect of IGF-I by $50 \%$ in the presence of high glucose. PD98059 and U0126 had no significant effect on apoptosis in control cells. However, LY294002 alone increased apoptosis by $20 \%$ in 


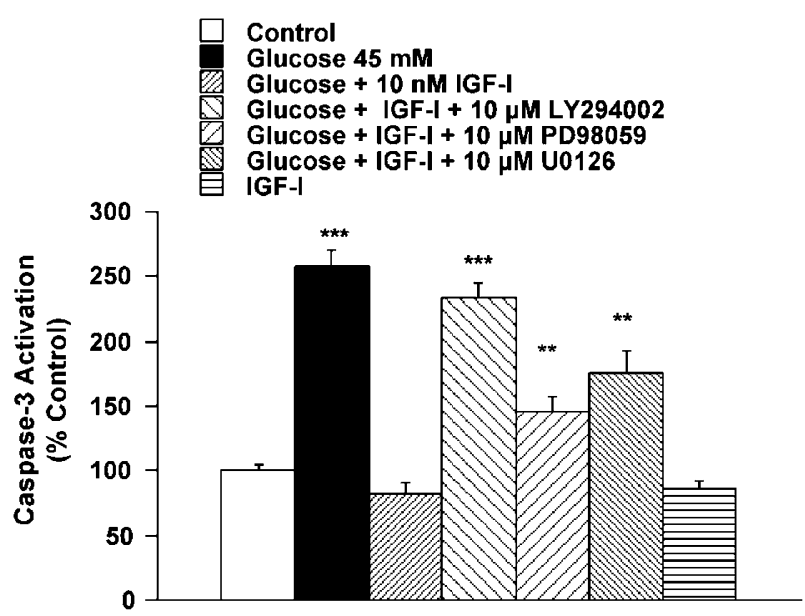

Figure 7 IGF-I blocks activation of caspase-3 in SH-SY5Y cells through a PI3K-dependent mechanism. SH-SY5Y cells were cultured in control or $45 \mathrm{mM}$ total glucose for a period of $6 \mathrm{~h}$, and then caspase-3 activation was measured using a DEVD-AMC fluorogenic substrate in the presence of PI exclusion. The graph indicates $\%$ control (where control=100\%). IGF-I (10 nM) inhibits apoptosis in the presence of added glucose, an effect that is blocked by LY294002 and to a lesser extent by PD98059 and U0126. IGF-I alone marginally decreased caspase-3 activation below control levels. ${ }^{\star \star} P<0.01 ;{ }^{* \star *} P<0.001$ compared to control

control cells, although it does not further increase glucoseinduced apoptosis (data not shown).

\section{Glucose activates initiator caspases}

MMD often leads to the release of cytochrome $c$ from the mitochondria, followed by formation of the apoptosome, a complex formed by cytochrome $c$, Apaf-1 and caspase- 9 binding. ${ }^{33-36}$ This in turn promotes caspase- 9 cleavage and activation of the downstream caspase cascade. ${ }^{33-36}$ To test whether caspase-9 is involved in glucose-mediated apoptosis, SH-SY5Y cells were stably transfected with caspase-9 dominant-negative (C9DN) constructs. As a control, SHSY5Y cells were also transfected with caspase-8 dominantnegative constructs (C8DN), as caspase- 8 activation is normally activated by death receptor induction rather than mitochondrial events. Transfected cells were then exposed to increasing concentrations of glucose and apoptosis measured using PI staining. As previously discussed, $175 \mathrm{mM}$ glucose increases apoptosis in control, vector-transfected cells; however, this increases three-fold in $325 \mathrm{mM}$ glucose at $24 \mathrm{~h}$ (Figure 8a). Interestingly, when cells are transfected with C8DN, apoptosis levels are approximately $60-70 \%$ of vector control cells (Figure 8a). C9DN expressing cells show apoptosis levels of approximately $20 \%$ of vector control cells (Figure $8 b$ ). These data suggest that although caspase- 8 is responsible for a portion of the apoptosis seen in glucosetreated SH-SY5Y cells, caspase-9 plays a larger role.

We next investigated the time course over which caspase$8,-9$ and -3 are activated in response to $325 \mathrm{mM}$ glucose, the dose that produces the greatest amount of apoptosis in $\mathrm{SH}$ SY5Y cells. Caspase-8, a 55/53 kDa protein, is cleaved into several products, including $43 / 41,26 / 24$ and $18 \mathrm{kDa}$ products. ${ }^{50}$ The $55 \mathrm{kDa}$ proform is found in every condition,

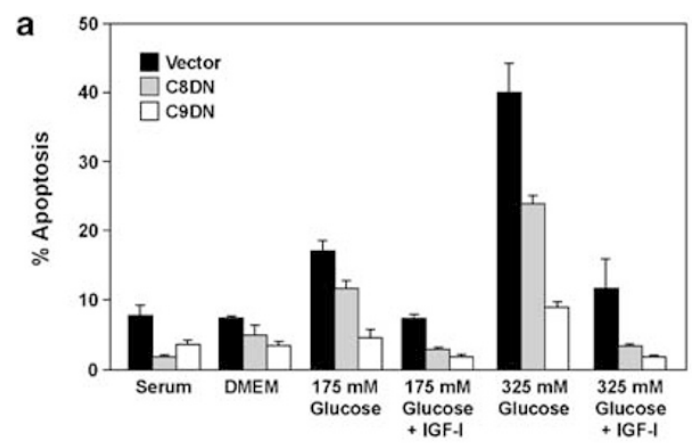

b

Time

$\begin{array}{llllllllll}(\min ) & 0 & 5 & 10 & 15 & 20 & 30 & 40 & 50 & 60\end{array}$

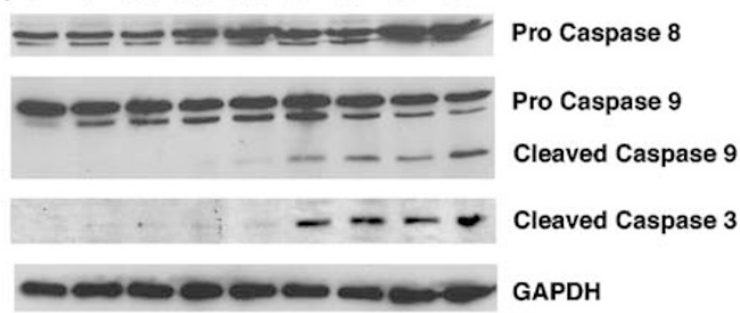

C

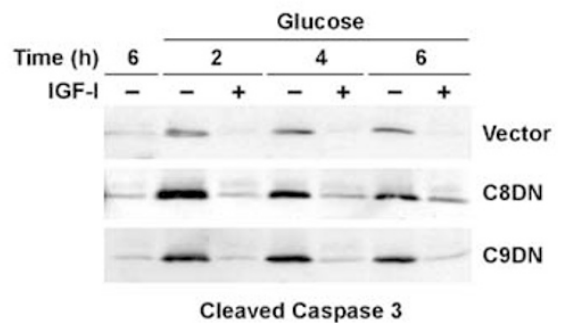

Figure 8 Caspase-9 mediates apoptosis induced by high glucose in SH-SY5Y neuroblastoma cells. (a) SH-SY5Y cells stably transfected with vector, dominantnegative caspase-8 (C8DN) or dominant-negative caspase-9 (C9DN) constructs were treated with 25,175 or $325 \mathrm{mM}$ glucose $\pm 10 \mathrm{nM}$ IGF-I for $24 \mathrm{~h}$. Cells were then analyzed for apoptosis via flow cytometry. C9DN cells treated with $325 \mathrm{mM}$ glucose exhibit significantly less apoptosis than vector cells $(P<0.001)$. Addition of IGF-I to $325 \mathrm{mM}$ glucose inhibits apoptosis significantly in vector, C8DN and C9DN cells $(P<0.001)$. (b) SH-SY5Y cells were treated with control DMEM media for $60 \mathrm{~min}$ (c) or $325 \mathrm{mM}$ glucose for $5-60 \mathrm{~min}$ as indicated. Cells were analyzed for caspase cleavage via Western immunoblotting. Levels of the caspase-8 proform $(55 \mathrm{kDa})$ do not change upon glucose exposure. In contrast, caspase- 9 and caspase-3 show increased cleavage after $30 \mathrm{~min}$ of high-glucose treatment (37 and $17 \mathrm{kDa}$, respectively). Equal protein loading between samples is shown with the GAPDH blot presented. (c) SH-SY5Y cells stably transfected with vector, C8DN or C9DN constructs were treated with control DMEM media for $6 \mathrm{~h}$ or with $325 \mathrm{mM}$ glucose $\pm 10 \mathrm{nM} \mathrm{IGF}-\mathrm{I}$ for 2,4 or $6 \mathrm{~h}$ as indicated. Cells were then analyzed for caspase-3 cleavage via Western immunoblotting. A caspase-3 cleavage band $(17 \mathrm{kDa}$ ) is detected in all three cell lines in $325 \mathrm{mM}$ glucose. IGF-I addition prevents the appearance of the caspase- 3 cleavage band in all three cell lines

unregulated by glucose exposure (Figure 8b). Interestingly, the 18 cleavage product, which is the active subunit capable of cleaving downstream caspases, is undetectable in glucosetreated SH-SY5Y cells. In contrast, the $35 \mathrm{kDa}$ caspase- 9 cleavage product, absent in untreated samples, is detected within 30 min of exposure to high glucose and remains steady through $60 \mathrm{~min}$. (Figure 8b). The caspase-9 cleavage corresponds to the time course of caspase- 3 cleavage at this high glucose dose (Figure 8b). This indicates that glucosemediated apoptosis in SH-SY5Y cells may occur through 
regulation of the caspase-9-dependent pathway. Furthermore, these caspase-mediated events begin prior to mitochondrial disruption.

Finally, we examined the effect of IGF-I on glucosemediated apoptosis in the C8DN and C9DN SH-SY5Y cells. IGF-I protects $60-75 \%$ of SH-SY5Y cells from glucosemediated apoptosis in vector-transfected control cells (Figure 8a). Interestingly, the IGF-I and C8DN or C9DN constructs have an additive effect on protection, with the combination of both IGF-I and caspase inhibition protecting more than $96 \%$ of cells (Figure $8 \mathrm{a}$ ). Therefore, IGF-I likely exerts protective effects on SH-SY5Y cells independent of initiator caspase regulation. To confirm these observations at the caspase-3 level, vector-transfected control, C8DN and C9DN cells were exposed to high glucose (325 mM) for 2, 4 and $6 \mathrm{~h}$, time points prior to mitochondrial dysfunction. At each time point, caspase-3 is cleaved in all three cell lines with glucose exposure (Figure $8 \mathrm{c}$ ). This observation suggests that caspase- 3 is cleaved independent of caspase- 8 or caspase- 9 in SH-SY5Y cells. IGF-I prevents caspase-3 cleavage at every time point (Figure 8c), consistent with our previous results. Therefore, our studies suggest that caspase- 3 is activated very early after glucose exposure, independent of caspase- 8 or caspase- 9 cleavage. An additional activation of caspase-3 occurs after MMD, which is dependent on PTP opening. Therefore, caspase- 3 is activated in multiple, likely parallel, places along the apoptotic cascade in response to glucose exposure. However, IGF-I prevents caspase-3 activation in each case, providing the greatest amount of protection against glucose-induced apoptosis.

\section{Discussion}

Proteins involved in apoptosis are often altered in aggressive neuroblastoma tumors. ${ }^{4,51}$ In particular, the proapoptotic protein caspase- 8 is frequently absent or inactive, and the antiapoptotic protein $\mathrm{Bcl}-2$ is often upregulated. ${ }^{4,52}$ Therefore, understanding alternative methods of apoptosis induction in neuroblastoma cells is critical for future treatment development.

Recent studies indicate that mitochondria play a central role in most forms of apoptosis. ${ }^{24,25}$ For example, cytochrome $c$ is lost by mitochondria to the cytosol where it acts as a cofactor for caspase activation. Also, Bcl-2 family proteins appear to carry out their functions, at least in part, by regulating $\Delta \Psi_{\mathrm{M}}$ and mitochondrial volume. ${ }^{24,27,53}$ Moreover, kinetic data show that mitochondria undergo major changes in membrane permeability, polarity and volume prior to other well-recognized signs of apoptosis such as caspase activation and chromatin condensation. ${ }^{25}$ In neuroblastoma, doxorubicin induces apoptosis in caspase-deficient cells through direct effects on the mitochondria. ${ }^{54}$ Therefore, the current studies were carried out to determine the contribution of mitochondrial changes to apoptosis in neuroblastoma, with particular focus on identifying the cellular biochemical pathways that lead to apoptosis after high-glucose exposure.

In previous studies, we have shown that mannitol induces apoptosis in SH-SY5Y cells. ${ }^{5,18,41}$ However, high concentrations of mannitol are needed to induce apoptosis in these cells. ${ }^{5}$ We and others have shown that even a mild increase in extracellular glucose $(20 \mathrm{mM})$ enhances apoptosis in primary neuronal cells. ${ }^{44,47,48,55,56}$ Even at higher concentrations ( $>150 \mathrm{mM}$ ), cell death is considerably higher with equiosmolar glucose than with mannitol, indicating that glucose induces cell death independent of an osmolar effect and can be used at lower concentrations to initiate apoptosis. ${ }^{44,47}$ Therefore, we used glucose as a cell death inducer in the current study, as we could use milder conditions to investigate more fully the apoptotic mechanisms activated. In this study, glucose clearly induces a dose-dependent increase in caspase-3 cleavage. With $45 \mathrm{mM}$ total glucose used, in most of the experiments there is only a $5 \%$ increase in total osmolarity of the medium, insufficient to account for the observed apoptosis. ${ }^{47}$

In this study, we investigated the effect of increased glucose on the mitochondria. Hyperpolarization of $\Delta \Psi_{\mathrm{M}}$, an event associated with induction of apoptosis, ${ }^{44,57-59}$ is observed with addition of extracellular glucose and is maximal in this study at $3 \mathrm{~h}$, corresponding to early cleavage of caspase-3 at the same time point. One of the key events preceding apoptosis is a change in PTP. Mitochondrial permeability transition is associated with opening of the ANT/VDAC channel spanning the inner and outer mitochondrial membranes. This results in osmotic swelling that in turn disrupts the integrity of the outer mitochondrial membrane, ${ }^{60}$ and is associated with release of proapoptotic factors into the cytoplasm that activate the caspase cascade. ${ }^{24}$ In contrast, inhibition of the ANT/VDAC channel stabilizes $\Delta \Psi_{\mathrm{M}} \cdot{ }^{43}$ In this study, MMD induced by high glucose is blocked by BKA, a ligand for the ANT that inhibits opening of the ANT and stabilizes the inner mitochondrial membrane. ${ }^{42}$ Furthermore, BKA inhibits downstream cleavage of caspase-3 indicating that stabilization of $\Delta \Psi_{\mathrm{M}}$ in the presence of high glucose is important in preventing apoptosis. One important association of increased stability of $\Delta \Psi_{\mathrm{M}}$ is to prevent the loss of UCPs.

Glucose oxidation in the mitochondria leads to the supply of electrons to the electron transfer chain, leading to increased proton pumping from the mitochondria. Overproduction of electron donors by the tricarboxylic acid (TCA) cycle increases the proton gradient and results in an increased $\Delta \Psi_{\mathrm{M}}$ that would predispose the cell to the induction of apoptosis. The UCPs are inner mitochondrial membrane proteins that dissipate the proton electrochemical gradient as heat, that is, they uncouple mitochondrial electron transfer from oxidative phosphorylation and regulate mitochondrial proton conductance. ${ }^{61,62}$ Furthermore, overexpression of UCPs prevents apoptosis induction. ${ }^{57}$ UCP3 is expressed in skeletal muscle and neurons, and UCP2 in neurons. ${ }^{61,63,64}$ The UCPs also have sequence homology to mitochondrial transporters including the $\mathrm{Bcl}$ proteins, suggesting that they may be mitochondrial carriers. ${ }^{65-67}$ When UCP levels are reduced, $\Delta \Psi_{\mathrm{M}}$ is abnormally high, increasing back pressure on the inner mitochondrial membrane proton pumps, events that may further promote induction of apoptosis. In this study, UCP3 protein levels are decreased in the presence of high glucose and maintained by the presence of BKA consistent with regulation of UCPs by $\Delta \Psi_{\mathrm{M}}$. Interestingly in neurons, overexpression of UCPs prevents glucose-induced apoptosis, ${ }^{57}$ suggesting that similar to the Bcl proteins, UCPs may act as important regulators of apoptosis. 
Changes in PTP leading to mitochondrial swelling, MMD, cytochrome $c$ release and eventual caspase activation may also be due to regulation of $\mathrm{Bcl}$-2-related proteins. For example, $\mathrm{Bcl}-2$ possesses $\mathrm{BH} 1$ and $\mathrm{BH} 2$ domains that may have a pore-forming function in the mitochondrial membrane. This would counteract apoptosis by facilitating the activity of PTP, whereas Bax promotes apoptosis by inhibiting PTP activity. ${ }^{27,28}$ This concept was supported by our findings that elevated glucose causes a reduction in the levels of $\mathrm{Bcl}-2$, similar to our previous findings with mannitol exposure. ${ }^{17}$ However, $\mathrm{Bcl}-2$ is also expressed at extramitochondrial sites and may separately regulate apoptosis through Apaf- 1 and binding to the apoptosome. ${ }^{68}$

Normally, Apaf-1 binds to cytochrome $c$, released from the mitochondria, and caspase-9, which leads to caspase-9 cleavage and activation of the downstream caspase cascade. ${ }^{33-36}$ Many neuroblastoma tumors and cell lines show $\mathrm{N}$ Myc-independent defects in the caspase-8 signaling pathway, whereas the caspase- 9 pathway remains intact, ${ }^{69,70}$ suggesting that targeting this pathway is important for chemotherapeutic treatment. In the current study, glucose treatment induces caspase- 9 cleavage in neuroblastoma cells, and inhibition of this caspase prevents apoptosis. Caspase-8 inhibition also prevents apoptosis in a small percentage of cells, although no cleavage of this protein is detected. These results are similar to those seen in glucose-induced apoptosis in proximal tubular epithelial cells. ${ }^{71}$ Interestingly, C8DN cells show apoptosis inhibition even greater than C9DN in serumcontaining conditions. Therefore, C8DN may prevent basal levels of apoptosis in SH-SY5Y cells.

In contrast to caspase-8, in our study, caspase- 9 cleavage is regulated by glucose exposure, followed closely by caspase-3 activation at $30 \mathrm{~min}$. Furthermore, inhibition of caspase- 9 with the dominant-negative construct prevents over $80 \%$ of apoptosis in neuroblastoma cells. However, C9DN cells still show caspase-3 cleavage after glucose exposure, suggesting that caspase- 3 may be cleaved independently of caspase- 9 activation. Previous reports indicate that caspase- 9 and -3 operate in a feedback amplification loop, such that initial low levels of activated caspase- 9 lead to caspase- 3 activation, but full caspase- 9 processing is only achieved after caspase- 3 activation; this in turn leads to additional caspase- 3 activation. ${ }^{72}$ Therefore, we hypothesize that glucose induces caspase-3 activation through several parallel pathways, only one of which is caspase- 9 dependent. Furthermore, we believe that caspase3 and caspase- 9 act in an amplification loop, ultimately ensuring the apoptotic death of glucose-exposed neuroblastoma cells. In contrast, Bcl protein alterations, which would destabilize the mitochondrial membrane allowing cytochrome $c$ release, occur late in the apoptotic process. This suggests that glucose-mediated caspase- 9 activation occurs independent of mitochondrial involvement or $\mathrm{Bcl}$ protein expression changes. Early caspase activation could be mediated through Bax translocation. Bax translocation from the cytosol to the mitochondria occurs within 30 min of staurosporine treatment in SH-SY5Y cells. ${ }^{73}$ Bax translocation is also induced by hypoxia and ATP depletion in kidney cells ${ }^{74}$ and by reactive oxygen species in cardiomyocytes. ${ }^{75}$ Since reactive oxygen species are produced by hyperglycemia, ${ }^{76}$ Bax translocation is a good candidate for an early event in glucose-mediated apoptosis. Upon insertion into the mitochondrial membrane, Bax may mediate cytochrome $c$ release, an event that can occur without permeability transition. ${ }^{43,73,77}$ We are currently investigating Bax translocation and cytochrome $c$ release in glucose-mediated apoptosis in neuroblastoma cells.

IGF-I signaling through the IGF-IR is important in cellular transformation and the proliferation of tumor cells, while disruption of the IGF-IR reverses the transformed phenotype. ${ }^{7,9-11}$ Therefore, targeting the IGF-IR provides a novel therapeutic approach for cancer treatment. ${ }^{12,20,21}$ In neuroblastoma, IGF-I leads to increased cell growth and survival. $^{6,10,13,14,16,17}$ Our current studies indicate that IGF-I is neuroprotective by blocking mitochondrial swelling, MMD and caspase-3 activation. IGF-I prevents mitochondrial events induced by several stressors in SH-SY5Y neuroblastoma cells. Mannitol-mediated MMD and subsequent apoptosis are inhibited by IGF-I. ${ }^{6}$ IGF-I also protects SY5Y cells from peroxynitrite-induced apoptosis by preventing cytochrome $c$ release and caspase- 3 activation. ${ }^{78}$ Finally, IGF-I induces UCP3 expression, ${ }^{79}$ which could counteract the effect of glucose on this protein.

Two important IGF-I signaling pathways, PI3K and MAPK, are implicated in the regulation of apoptosis. ${ }^{80,81}$ While there is previous evidence that IGF-I regulates $\Delta \Psi_{\mathrm{M}},{ }^{6}$ this study shows regulation of $\Delta \Psi_{\mathrm{M}}$ and mitochondrial enlargement by discrete signaling pathways. Overall, the data in this study indicate that the PI3K pathway is responsible for the inhibition of glucose-mediated MMD and apoptosis. There is further support for $\mathrm{PI} 3 \mathrm{~K}$ and downstream Akt regulation of $\mathrm{Bcl}-2$ in neuronal cells; LY294002 blocks the ability of IGF-I to maintain Bcl-2 expression during apoptosis, ${ }^{82}$ while a dominant-negative form of Akt eliminates the protective effects of IGF-I. ${ }^{82}$ Akt also acts downstream of IGF-I to prevent cytochrome $c$-induced caspase-3 activation in peroxynitrite-treated $\mathrm{SH}-\mathrm{SY} 5 \mathrm{Y}$ cells. ${ }^{78}$ In mesangial cells, IGF-I prevents glucose-mediated apoptosis and mitochondrial changes via both the PI3K and MAPK pathways. ${ }^{83}$ However, in our study, inhibition of the MAPK/MEK pathway independently and partially blocked IGF-I inhibition of MMD, but did not significantly affect IGF-I mitochondrial enlargement, indicating that IGF-I regulates different components of mitochondrial function through discrete signaling pathways.

Collectively, our studies indicate that changes in $\Delta \Psi_{M}$ are central to apoptosis and induced by increases in extracellular glucose. This change in the function of PTP is linked to a reduction in UCP2 and 3, altered Bcl-2 activity and activation of caspases. In contrast, IGF-I regulates $\Delta \Psi_{\mathrm{M}}$ and glucoseinduced apoptosis via discrete signaling pathways. Together, our results suggest that the following pathway contributes to glucose-induced apoptosis in neuroblastoma: (i) caspase- 9 is activated; (ii) PTP function is reduced; (iii) mitochondrial membranes are disrupted, releasing proapoptotic proteins and activated caspases, initiating the execution phase of apoptosis; and (iv) Bcl-2 protein levels are altered, ensuring an apoptotic death. Therefore, initiation of this cascade of events could promote apoptosis in aggressive neuroblastoma tumors resistant to other treatment strategies. 


\section{Materials and Methods}

\section{Materials}

Tissue culture plastic was purchased from Corning (Corning, NY, USA). Dulbecco's modified Eagle's medium (DMEM), Hank's balanced salt solution (HBSS), trypsin-EDTA and calf serum (CS) were purchased from Gibco BRL (Gaithersburg, MD, USA). IGF-I was provided by Cephalon, Inc. (Westchester, PA, USA). BKA, LY294002, PD98059 and U0126 were from Biomol (Plymouth Meeting, PA, USA). The caspase-3 fluorometric assay kit was from PharMingen (San Diego, CA, USA). Bcl-2 antibodies were obtained from Santa Cruz (SC-7382, Santa Cruz, CA, USA), caspase-3 antiactive rabbit polyclonal antibodies (Asp 175) and caspase-9 antibodies were from Cell Signaling (Beverly, MA, USA), caspase-8 antibody was from Calbiochem (Cat \#218778; San Diego, CA, USA), UCP3 antibodies were from Research Diagnostics Inc. (Flanders, NJ, USA) and GAPDH monoclonal antibody was from Chemicon (Temecula, $\mathrm{CA}, \mathrm{USA})$. Enhanced chemiluminescence (ECL) reagents and molecular weight standards were from Amersham (Arlington Heights, IL, USA). All other chemicals were purchased from Sigma-Aldrich (St. Louis, MO, USA).

\section{Cell culture}

SH-SY5Y human neuroblastoma cells were grown in DMEM with $10 \%$ calf serum at $37^{\circ} \mathrm{C}$ in a humidified atmosphere containing $10 \% \mathrm{CO}_{2}$ as described previously. ${ }^{5}$ In experiments, cells were subcultured in DMEM alone with the experimental condition. Control DMEM contains $25 \mathrm{mM}$ basal glucose; all additional glucose concentrations are expressed as total glucose levels $(25 \mathrm{mM}$ control glucose concentration + exogenous glucose concentration). SH-SY5Y cells were stably transfected with pCDNA3 vector control, dominant-negative caspase-8 (C8DN) or dominant-negative caspase-9 (C9DN) constructs, kindly provided by $\mathrm{Dr}$. Vishva Dixit, Genentech (CA), formerly of the University of Michigan. These dominant-negative constructs contain point mutations at the active cysteine site to an alanine residue, resulting in caspases that can be cleaved, but are not capable of cleaving downstream targets. ${ }^{84,85}$ Cells were selected for at least 1 month in DMEM $+500 \mu \mathrm{M}$ G418 prior to use.

\section{Isolation of mitochondrial and cytosolic fractions}

Differential centrifugation of SH-SY5Y cells was used to isolate mitochondrial and cytosolic fractions as described previously. ${ }^{27}$ For FACS analysis, the following isolation method was used: cells were lysed with a tissue tearator while suspended in ice-cold buffer A containing $250 \mathrm{mM}$ sucrose, $20 \mathrm{mM}$ HEPES, $10 \mathrm{mM} \mathrm{KCl}, 1.5 \mathrm{mM} \mathrm{MgCl}_{2}, 1 \mathrm{mM}$ EDTA, $1 \mathrm{mM}$ EGTA, $1 \mathrm{mM}$ DTT, $17 \mu \mathrm{g} / \mathrm{ml}$ phenylmethylsulfonyl fluoride, $8 \mu \mathrm{g} / \mathrm{m}$ aprotinin and $2 \mu \mathrm{g} / \mathrm{ml}$ leupeptin at $\mathrm{pH} 7.4$. Unlysed cells and nuclei were pelleted at $750 \times g$ for $10 \mathrm{~min}$, then the supernatant was spun at $10000 \times g$ for $25 \mathrm{~min}$ and the pellet was resuspended in buffer $A$. This represents the mitochondrial fraction. The supernatant is then spun at $100000 \times g$ for $1 \mathrm{~h}$, and the supernatant from this spin represents the cytosolic fraction.

\section{Analysis of mitochondrial membrane polarity in whole cells}

SH-SY5Y cells were plated at $1 \times 10^{5} \mathrm{cell} / \mathrm{s} / \mathrm{cm}^{2}$ in six-well plates. After reaching approximately $90 \%$ confluence, cells were placed in serum-free DMEM and the experimental condition. Rh123 is a potentiometric dye that is preferentially taken up by mitochondria. A decrease in Rh123 levels is consistent with MMD. Cells were then incubated with $5 \mu \mathrm{g} / \mathrm{ml} \mathrm{Rh123}$ for $30 \mathrm{~min}$ at $37^{\circ} \mathrm{C}$. Next, cells were removed from plates with trypsin-EDTA and combined with medium to collect all cells. Following centrifugation at $500 \times g$, the trypsinized cells were washed with HBSS (without $\mathrm{Ca}^{2+}$, $\mathrm{Mg}^{2+}$ and phenol red). The cells were then stained for 15 min with $18 \mu \mathrm{g} /$ $\mathrm{ml} \mathrm{PI}$ in the presence of $40 \mu \mathrm{g} / \mathrm{ml}$ RNAse A, followed by washing in HBSS. Live cells were then analyzed using an Epics Elite FACS system (Coulter Cytometry, Hialeah, FL, USA) reading Rh123 (absorbance: $\pm 480 \mathrm{~nm}$, emission: $\pm 530 \mathrm{~nm}$ ), and using gating against $\mathrm{PI}$ to indicate PI exclusion (live cells).

\section{Determination of mitochondrial size using FLS}

Mitochondria were isolated as described above, stained with $2.5 \mu \mathrm{g} / \mathrm{ml}$ Rh123 in buffer A for $30 \mathrm{~min}$, and then washed with cold MSH buffer (210 mM mannitol, $70 \mathrm{mM}$ sucrose, $10 \mathrm{mM}$ HEPES, $0.2 \mathrm{mM}$ EGTA, $5 \mathrm{mM}$ succinate, $0.15 \% \mathrm{BSA}, 5 \mu \mathrm{M}$ rotenone, $0.01 \%$ saponin) to stabilize the mitochondria prior to FACS analysis. The mitochondria were repelleted at $10000 \times g$, resuspended in MSH buffer, and FACS analysis with FLS was performed as described previously. ${ }^{27}$ Measurements from experimental mitochondria were compared against control mitochondria, and 1-10 $\mu \mathrm{m}$ measurement beads. Mitochondria were examined histologically to confirm pure isolates and to confirm morphological integrity of the inner and outer membranes.

\section{Immunoblotting for caspases, Bcl and UCP proteins}

SH-SY5Y cells were plated at an initial density of $5 \times 10^{6}$ cells $/ \mathrm{cm}^{2}$ and grown to approximately $90 \%$ confluence. Cells were washed twice with DMEM before experimental treatments. Western blots were performed as described previously ${ }^{86}$ using $30-75 \mu \mathrm{g}$ of total protein for each sample. The same quantity of protein was loaded in each well. Anti-Bcl-2 immunoblotting was performed using $0.1 \mu \mathrm{g} / \mathrm{ml}$ rabbit polyclonal antibody. Anti-caspase-3 polyclonal antibody was used at a $1: 1000$ dilution for $2 \mathrm{~h}$ and probed with secondary goat anti-rabbit at a dilution of $1: 2500$ for $1 \mathrm{~h}$. UCP3 polyclonal antibody was used at a 1:1000 dilution, and secondary goat anti-rabbit at $1: 2500$. GAPDH monoclonal antibody was used at a dilution of 1:300. Immunoblots were exposed following ECL reaction (Amersham, Arlington Heights, IL, USA) to autoradiography film (Hyperfilm-MP, Amersham). Immunoblots shown are one of at least three independent experiments. GAPDH antibody $(36 \mathrm{kDa})$ was used as a loading control, and was applied to the same blot for antiactive caspase-3. Blots for Bcl-2 and UCP3 were stripped and reprobed with anti-GAPDH.

\section{Caspase- 3 activation assay}

A caspase-3 fluorometric assay kit from Pharmingen (San Diego, CA, USA) was used for the determination of caspase-3 activation within cells. The assay was conducted according to the manufacturer's instructions ${ }^{87}$ and in conjunction with an Epics Elite flow cytometry system using excitation at $380 \mathrm{~nm}$ and emission at $440 \mathrm{~nm}$. All experiments were conducted with the following controls: cell lysate alone, Ac-DEVD-AMC alone, non-apoptotic cells and positive apoptotic controls. Caspase cleavage was gated against PI (to determine cell viability) using FACS, and the mean of the peak caspase- 3 level and percent cells expressing cleaved caspase- 3 were measured. 


\section{Flow cytometry}

Analysis of DNA content was performed using flow cytometry. Cells were plated in six-well plates at $1 \times 10^{5} \mathrm{cells} / \mathrm{cm}^{2}$. After reaching near confluency, cells were serum deprived for $4 \mathrm{~h}$ and exposed to experimental conditions for the indicated times. Cells were removed from the plates with trypsin-EDTA, rinsed in HBSS, fixed in ice-cold $70 \%$ ethanol and stored at $4^{\circ} \mathrm{C}$. Cells were stained for $2-12 \mathrm{~h}$ with $18 \mu \mathrm{g} / \mathrm{ml} \mathrm{PI}$ and $40 \mu \mathrm{g} / \mathrm{ml}$ RNase $A$ at $4^{\circ} \mathrm{C}$. DNA content of Pl-stained cells was measured and separated into phases of the cell cycle based on the PI fluorescence. Percent apoptotic cells in all cases was taken as percent sub-g $g_{0}$ DNA as measured on an Epics Elite flow cytometry system (Coulter Cytometry, Hialeah, FL, USA). All results are expressed as the mean percent apoptotic cells of three experiments \pm standard error of the mean (S.E.M.).

\section{Statistical analysis}

Assumptions about the Gaussian distribution of data and rules for transformation of non-normative data were made as described previously. ${ }^{47}$ Comparison of dependent variables was performed using factorial analysis of variance (ANOVA). Unless otherwise indicated, experiments were replicated at least three times, and data pooled after standardization against matching control values. An observer blinded to the experimental condition made measurements. For graphic and descriptive purposes, data are expressed as value \pm S.E.M.

\section{Acknowledgements}

This work was supported in part by NIH NS42056, The Juvenile Diabetes Research Foundation Center for the Study of Complications in Diabetes (JDRF), Office of Research Development (Medical Research Service), Department of Veterans Affairs (JWR); NIH NS36778, NIH NS38849, and grants from the JDRF and Program for Understanding Neurological Diseases (ELF); NIDDK \#P60DK-20572 - Michigan Diabetes Research and Training Center; University of Michigan Core Flow Cytometry facility (supported in part by the UM-Comprehensive Cancer Center NIH P30 CA46592 and the UM-Multipurpose Arthritic Center NIH AR20557). We extend our appreciation to Dr. T Schwab, Ms. K Cherian and Mr. A. Parekh for assistance with experiments and to Dr. B Kim for aid in manuscript preparation.

\section{References}

1. Bown N (2001) Neuroblastoma tumour genetics: clinical and biological aspects. J. Clin. Pathol. 54: 897-910

2. Westermann F and Schwab M (2002) Genetic parameters of neuroblastomas. Cancer Lett. 184: 127-147

3. Kim PK, Mahidhara R and Seol DW (2001) The role of caspase-8 in resistance to cancer chemotherapy. Drug Resist. Update. 4: 293-296

4. Teitz T, Lahti JM and Kidd VJ (2001) Aggressive childhood neuroblastomas do not express caspase-8: an important component of programmed cell death. J. Mol. Med. 79: 428-436

5. van Golen CM and Feldman EL (2000) Insulin-like growth factor I is the key growth factor in serum that protects neuroblastoma cells from hyperosmoticinduced apoptosis. J. Cell. Physiol. 182: 24-32

6. van Golen CM, Castle VP and Feldman EL (2000) IGF-I receptor activation and $\mathrm{Bcl}-2$ overexpression prevent early apoptotic events in human neuroblastoma. Cell Death Differ. 7: 654-665

7. Adams TE, Epa VC, Garrett TP and Ward CW (2000) Structure and function of the type 1 insulin-like growth factor receptor. Cell. Mol. Life Sci. 57: 1050-1093
8. Nechushtan A, Smith CL, Hsu YT and Youle RJ (1999) Conformation of the Bax C-terminus regulates subcellular location and cell death. EMBO J. 18: 2330-2341

9. Baserga $R(2000)$ The contradictions of the insulin-like growth factor 1 receptor. Oncogene 19: 5574-5581

10. Singleton JR, Randolph AE and Feldman EL (1996) Insulin-like growth factor I receptor prevents apoptosis and enhances neuroblastoma tumorigenesis. Cancer Res. 56: 4522-4529

11. Surmacz E, Guvakova MA, Nolan MK, Nicosia RF and Sciacca L (1998) Type I insulin-like growth factor receptor function in breast cancer. Breast Cancer Res. Treat. 47: 255-267

12. Butler AA, Blakesley VA, Tsokos M, Pouliki V, Wood TL and LeRoith D (1998) Stimulation of tumor growth by recombinant human insulin-like growth factor-l (IGF-I) is dependent on the dose and the level of IGF-I receptor expression. Cancer Res. 58: 3021-3027

13. Sullivan KA, Castle VP, Hanash SM and Feldman EL (1995) Insulin-like growth factor II in the pathogenesis of human neuroblastoma. Am. J. Pathol. 147: 1790-1798

14. Leventhal PS, Randolph AE, Vesbit TE, Schenone A, Windebank AJ and Feldman EL (1995) Insulin-like growth factor-II as a paracrine growth factor in human neuroblastoma cells. Exp. Cell Res. 221: 179-186

15. Kiess W, Koepf G, Christiansen H and Blum WF (1997) Human neuroblastoma cells use either insulin-like growth factor-I or insulin-like growth factor-II in an autocrine pathway via the IGF-I receptor: variability of IGF, IGF binding protein (IGFBP) and IGF receptor gene expression and IGF and IGFBP secretion in human neuroblastoma cells in relation to cellular proliferation. Regul. Pept. 72 : $19-29$

16. Liu X, Turbyville T, Fritz A and Whitesell L (1998) Inhibition of insulin-like growth factor I receptor expression in neuroblastoma cells induces the regression of established tumors in mice. Cancer Res. 58: 5432-5438

17. Singleton JR, Dixit VM and Feldman EL (1996) Type I insulin-like growth factor receptor activation regulates apoptotic proteins. J. Biol. Chem. 271: 31791-31794

18. Matthews CC, Odeh H and Feldman EL (1997) Insulin-like growth factor-I is an osmoprotectant in human neuroblastoma cells. Neuroscience 79 : $525-534$

19. van Golen CM, Schwab TS, Woods Ignatoski KM, Ethier SP and Feldman EL (2001) PTEN/MMAC1 overexpression decreases insulin-like growth factor-lmediated protection from apoptosis in neuroblastoma cells. Cell Growth Differ. 12: $371-378$

20. Blakesley VA, Stannard BS, Kalebic T, Helman LJ and LeRoith D (1997) Role of the IGF-I receptor in mutagenesis and tumor promotion. J. Endocrinol. 152: $339-344$

21. Werner $H$ (1998) Dysregulation of the type 1 IGF receptor as a paradigm in tumor progression. Mol. Cell. Endocrinol. 141: 1-5

22. Scotlandi K, Maini C, Manara MC, Benini S, Serra M, Cerisano V, Strammiello R, Baldini N, Lollini PL, Nanni P, Nicoletti G and Picci P (2002) Effectiveness of insulin-like growth factor I receptor antisense strategy against Ewing's sarcoma cells. Cancer Gene Ther. 9: 296-307

23. Li S, Ferber A, Miura M and Baserga R (1994) Mitogenicity and transforming activity of the insulin-like growth factor-I receptor with mutations in the tyrosine kinase domain. J. Biol. Chem. 269: 32558-32564

24. Green DR and Reed JC (1998) Mitochondria and apoptosis. Science 281 1309-1312

25. Kroemer G, Zamzami N and Susin SA (1997) Mitochondrial control of apoptosis. Immunol. Today 18: 44-51

26. Susin SA, Lorenzo HK, Zamzami N, Marzo I, Brenner C, Larochette N, Prevost MC, Alzari PM and Kroemer G (1999) Mitochondrial release of caspase-2 and 9 during the apoptotic process. J. Exp. Med. 189: 381-394

27. Vander Heiden MG, Chandel NS, Williamson EK, Schumacker PT and Thompson CB (1997) Bcl-xl regulates the membrane potential and volume homeostasis of mitochondria. Cell 91: 627-637

28. Vander Heiden MG, Chandel NS, Li XX, Schumacker PT, Colombini M and Thompson CB (2000) Outer mitochondrial membrane permeability can regulate coupled respiration and cell survival. Proc. Natl. Acad. Sci. USA 97: 4666-4671

29. Bossy-Wetzel E, Newmeyer DD and Green DR (1998) Mitochondrial cytochrome $c$ release in apoptosis occurs upstream of DEVD-specific caspase activation and independently of mitochondrial transmembrane depolarization. EMBO J. 17: 37-49 
30. Deshmukh M and Johnson EM (1998) Evidence of a novel event during neuronal death: development of competence-to-die in response to cytoplasmic cytochrome c. Neuron 21: 695-705

31. Budd SL, Tenneti L, Lishnak T and Lipton SA (2000) Mitochondrial and extramitochondrial apoptotic signaling pathways in cerebrocortical neurons. Proc. Natl. Acad. Sci. USA 97: 6161-6166

32. Luetjens CM, Bui NT, Sengpiel B, Munstermann G, Poppe M, Krohn AJ, Bauerbach E, Krieglstein J and Prehan JH (2000) Delayed mitochondrial dysfunction in excitotoxic neuron death: cytochrome $c$ release and a secondary increase in superoxide production. J. Neurosci. 20: 5715-5723

33. Villa P, Kaufmann SH and Earnshaw WC (1997) Caspases and caspase inhibitors. Trends Biochem. Sci. 22: 388-393

34. Li P, Nijhawan D, Budihardjo I, Srinivasula SM, Ahmad M, Alnemri ES and Wang X (1997) Cytochrome $C$ and dATP-dependent formation of Apaf-1/ caspase-9 complex initiates an apoptotic protease cascade. Cell 91: 479-489

35. Pan G, O'Rourke K and Dixit VM (1998) Caspase-9, Bcl-XL, and Apaf-1 form a ternary complex. J. Biol. Chem. 273: 5841-5845

36. Zou H, Henzel WJ, Liu X, Lutschg A and Wang X (1997) Apaf-1, a human protein homologous to $C$. elegans CED-4, participates in cytochrome $c$ dependent activation of caspase-3. Cell 90: 405-413

37. Maruyama W, Yamamoto T, Kitani K, Carrillo MC, Youdim M and Naoi M (2000) Mechanism underlying anti-apoptotic activity of a (-)deprenyl-related propargylamine, rasagiline. Mech. Ageing Dev. 116: 181-191

38. Moriya R, Uehara T and Nomura $Y(2000)$ Mechanism of nitric oxide-induced apoptosis in human neuroblastoma SH-SY5Y cells. FEBS Lett. 484: 253-260

39. Ronot X, Benel L, Adolphe M and Mounolou JC (1986) Mitochondrial analysis in living cells: the use of rhodamine 123 and flow cytometry. Biol. Cell 57: 1-7

40. Nicoletti I, Migliorati G, Pagliacci MC, Grignani F and Riccardi C (1991) A rapid and simple method for measuring thymocyte apoptosis by propidium iodide staining and flow cytometry. J. Immunol. Methods 139: 271-279

41. Matthews CC and Feldman EL (1996) Insulin-like growth factor I rescues SHSY5Y human neuroblastoma cells from hyperosmotic induced programmed cell death. J. Cell. Physiol. 166: 323-331

42. Zamzami N, El Hamel C, Maisse C, Brenner C, Munoz-Pinedo C, Belzacq AS, Costantini P, Vieira H, Loeffler M, Molle G and Kroemer G (2000) Bid acts on the permeability transition pore complex to induce apoptosis. Oncogene 19: $6342-6350$

43. Eskes R, Antonsson B, Osen-Sand A, Montessuit S, Richter C, Sadoul R, Mazzei G, Nicholas A and Martinou JC (1998) Bax-induced cytochrome C release from mitochondria is independent of the permeability transition pore but highly dependent on $\mathrm{Mg}^{2+}$ ions. J. Cell Biol. 143: 217-224

44. Russell JW, Golovoy D, Vincent AM, Mahendru P, Olzmann JA, Mentzer A and Feldman EL (2002) High glucose-induced oxidative stress and mitochondrial dysfunction in neurons. FASEB J. 16: 1738-1748

45. Zamzami N, Susin SA, Marchetti P, Hirsch T, Gomez-Monterrey I, Castedo M and Kroemer G (1996) Mitochondrial control of nuclear apoptosis. J. Exp. Med. 183: $1533-1544$

46. Narita M, Shimizu S, Ito T, Chittenden T, Lutz RJ, Matsuda H and Tsujimoto $Y$ (1998) Bax interacts with the permeability transition pore to induce permeability transition and cytochrome $c$ release in isolated mitochondria. Proc. Natl. Acad. Sci. USA 95: 14681-14686

47. Russell JW, Sullivan KA, Windebank AJ, Herrmann DN and Feldman EL (1999) Neurons undergo apoptosis in animal and cell culture models of diabetes. Neurobiol. Dis. 6: 347-363

48. Russell JW and Feldman EL (1999) Insulin-like growth factor-I prevents apoptosis in sympathetic neurons exposed to high glucose. Horm. Metab. Res. 31: $90-96$

49. Mack A, Furmann C and Hacker G (2000) Detection of caspase-activation in intact lymphoid cells using standard caspase substrates and inhibitors J. Immunol. Methods 241: 19-31

50. Scaffidi C, Medema JP, Krammer PH and Peter ME (1997) FLICE is predominantly expressed as two functionally active isoforms, caspase-8/a and caspase-8/b. J. Biol. Chem. 272: 26953-26958

51. Yamanaka $Y$, Hamazaki $Y$, Sato $Y$, Ito $K$, Watanabe $K$, Heike $T$, Nakahata $T$ and Nakamura $Y$ (2002) Maturational sequence of neuroblastoma revealed by molecular analysis on cDNA microarrays. Int. J. Oncol. 21: 803-807

52. Takita J, Yang HW, Chen YY, Hanada R, Yamamoto K, Teitz T, Kidd V and Hayashi $Y$ (2001) Allelic imbalance on chromosome $2 q$ and alterations of the caspase 8 gene in neuroblastoma. Oncogene 20: 4424-4432
53. Goping IS, Gross A, Lavoie JN, Nguyen M, Jemmerson R, Roth K, Korsmeyer SJ and Shore GC (1998) Regulated targeting of BAX to mitochondria. J. Cell Biol. 143: 207-215

54. Rebbaa A, Chou PM, Emran M and Mirkin BL (2001) Doxorubicin-induced apoptosis in caspase-8-deficient neuroblastoma cells is mediated through direct action on mitochondria. Cancer Chemother. Pharmacol. 48: 423-428

55. Schmeichel AM, Schmelzer JD and Low PA (2003) Oxidative injury and apoptosis of dorsal root ganglion neurons in chronic experimental diabetic neuropathy. Diabetes 52: 165-171

56. Srinivasan S, Stevens MJ and Wiley JW (2000) Diabetic peripheral neuropathy: evidence for apoptosis and associated mitochondrial dysfunction. Diabetes 49: 1932-1938

57. Vincent AM, Brownlee M and Russell JW (2002) Oxidative stress and programmed cell death in diabetic neuropathy. Ann. NY Acad. Sci. 959: 368-383

58. Poppe M, Reimertz C, Dussmann H, Krohn AJ, Luetjens CM, Bockelmann D, Nieminen AL, Kogel D and Prehn JH (2001) Dissipation of potassium and proton gradients inhibits mitochondrial hyperpolarization and cytochrome $c$ release during neural apoptosis. J. Neurosci. 21: 4551-4563

59. Liu X and Zhu XZ (1999) Roles of p53, c-Myc, Bcl-2, Bax and caspases in glutamate-induced neuronal apoptosis and the possible neuroprotective mechanism of basic fibroblast growth factor. Brain Res. Mol. Brain Res. 71: $210-216$

60. Kroemer G, Dallaporta B and Resche-Rigon M (1998) The mitochondrial death/ life regulator in apoptosis and necrosis. Annu. Rev. Physiol. 60: 619-642

61. Boss O, Muzzin P and Giacobino JP (1998) The uncoupling proteins, a review. Eur. J. Endocrinol. 139: 1-9

62. Guerra C, Benito M and Fernandez M (1994) IGF-I induces the uncoupling protein gene expression in fetal rat brown adipocyte primary cultures: role of $\mathrm{C} /$ EBP transcription factors. Biochem. Biophys. Res. Commun. 201: 813-819

63. Horvath TL, Warden CH, Hajos M, Lombardi A, Goglia F and Diano S (1999) Brain uncoupling protein 2: uncoupled neuronal mitochondria predict thermal synapses in homeostatic centers. J. Neurosci. 19: 10417-10427

64. Havel PJ, Hahn TM, Sindelar DK, Baskin DG, Dallman MF, Weigle DS and Schwartz MW (2000) Effects of streptozotocin-induced diabetes and insulin treatment on the hypothalamic melanocortin system and muscle uncoupling protein 3 expression in rats. Diabetes 49: 244-252

65. Boss O, Samec S, Paoloni-Giacobino A, Rossier C, Dulloo A, Seydoux J, Muzzin P and Giacobino JP (1997) Uncoupling protein-3: a new member of the mitochondrial carrier family with tissue-specific expression. FEBS Lett. 408: 39-42

66. Jezek P, Costa AD and Vercesi AE (1996) Evidence for anion-translocating plant uncoupling mitochondrial protein in potato mitochondria. J. Biol. Chem. 271: 32743-32748

67. Bairoch A (1993) The PROSITE dictionary of sites and patterns in proteins, its current status. Nucleic Acids Res. 21: 3097-3103

68. Adams JM and Cory S (1998) The Bcl-2 protein family: arbiters of cell survival. Science 281: 1322-1326

69. van Noesel MM, Pieters R, Voute PA and Versteeg R (2003) The N-myc paradox: N-myc overexpression in neuroblastomas is associated with sensitivity as well as resistance to apoptosis. Cancer Lett. 197: 165-172

70. Teitz T, Wei T, Liu D, Valentine V, Valentine M, Grenet J, Lahti JM and Kidd VJ (2002) Caspase-9 and Apaf-1 are expressed and functionally active in human neuroblastoma tumor cell lines with $1 \mathrm{p} 36 \mathrm{LOH}$ and amplified MYCN. Oncogene 21: $1848-1858$

71. Allen DA, Harwood S, Varagunam M, Raftery MJ and Yaqoob MM (2003) High glucose-induced oxidative stress causes apoptosis in proximal tubular epithelial cells and is mediated by multiple caspases. FASEB J. 17: 908-910

72. Fujita E, Egashira J, Urase K, Kuida K and Momoi T (2001) Caspase-9 processing by caspase-3 via a feedback amplification loop in vivo. Cell Death Differ. 8: 335-344

73. McGinnis KM, Gnegy ME and Wang KK (1999) Endogenous bax translocation in SH-SY5Y human neuroblastoma cells and cerebellar granule neurons undergoing apoptosis. J. Neurochem. 72: 1899-1906

74. Saikumar $P$, Dong $Y$, Patel $Y$, Hall $K$, Hopfer $U$, Weinberg $J$ and Venkatachalam MA (1999) Role of hypoxia-induced Bax translocation and cytochrome $c$ release in reoxygenation injury. Oncogene 17: 3401-3415

75. von Harsdorf R, Li P and Dietz R (1999) Signaling pathways in reactive oxygen species-induced cardiomyocyte apoptosis. Circulation 99: 2934-2941 
76. Feldman EL, Stevens MJ and Greene DA (1997) Pathogenesis of diabetic neuropathy. Clin. Neurosci. 4: 365-370

77. Jurgensmeier JM, Xie Z, Deveraux Q, Ellerby L, Bredesen D and Reed JC (1998) Bax directly induces release of cytochrome $c$ from isolated mitochondria. Proc. Natl. Acad. Sci. USA 95: 4997-5002

78. Saeki M, Maeda S, Wada K and Kamisaki Y (2002) Insulin-like growth factor-1 protects peroxynitrite-induced cell death by preventing cytochrome $c$-induced caspase-3 activation. J. Cell. Biochem. 84: 708-716

79. Gustafsson H, Adamson L, Hedander J, Walum E and Forsby A (2001) Insulinlike growth factor type 1 upregulates uncoupling protein 3. Biochem. Biophys. Res. Commun. 287: 1105-1111

80. Russell JW, Windebank AJ, Schenone A and Feldman EL (1998) Insulin-like growth factor-I prevents apoptosis in neurons after nerve growth factor withdrawal. J. Neurobiol. 36: 455-467

81. Ghatan S, Larner S, Kinoshita Y, Hetman M, Patel L, Xia Z, Youle RJ and Morrison RS (2000) p38 MAP kinase mediates bax translocation in nitric oxideinduced apoptosis in neurons. J. Cell Biol. 150: 335-347

82. Matsuzaki H, Tamatani M, Mitsuda N, Namikawa K, Kiyama H, Miyake S and Tohyama M (1999) Activation of Akt kinase inhibits apoptosis and changes in
Bcl-2 and Bax expression induced by nitric oxide in primary hippocampal neurons. J. Neurochem. 73: 2037-2046

83. Kang BP, Urbonas A, Baddoo A, Baskin S, Malhotra A and Meggs LG (2003) IGF-1 inhibits the mitochondrial apoptosis program in mesangial cells exposed to high glucose. Am. J. Physiol. Renal Physiol. 285: F1013-F1024

84. Chinnaiyan AM, O'Rourke K, Lane BR and Dixit VM (1997) Interaction of CED4 with CED-3 and CED-9: a molecular framework for cell death. Science 275: $1122-1126$

85. Duan CM, Hawes SB, Prevette T and Clemmons DR (1996) Insulin-like growth factor-I (IGF-I) regulates IGF-binding protein-5 synthesis through transcriptional activation of the gene in aortic smooth muscle cells. J. Biol. Chem. 271: 4280-4288

86. Leventhal PS and Feldman EL (1996) Tyrosine phosphorylation and enhanced expression of paxillin during neuronal differentiation in vitro. J. Biol. Chem. 271: 5957-5960

87. Delaney CL, Russell JW, Cheng H-L and Feldman EL (2001) Insulin-like growth factor-I and over-expression of Bcl-xL prevent glucose-mediated apoptosis in Schwann cells. J. Neuropathol. Exp. Neurol. 60: 147-160 